\title{
Mapping the Body and the Brain: Neurology and Localization Theory in the Work of Rodin
}

\section{Barbara Larson}

Volume 34, numéro 1, 2009

The Visual Culture of Science and Art in Fin-de-Siècle France La culture visuelle de la science et l'art dans la France fin-de-siècle

URI : https://id.erudit.org/iderudit/1069498ar

DOI : https://doi.org/10.7202/1069498ar

Aller au sommaire du numéro

\section{Éditeur(s)}

UAAC-AAUC (University Art Association of Canada | Association d'art des universités du Canada)

\section{ISSN}

0315-9906 (imprimé)

1918-4778 (numérique)

\section{Découvrir la revue}

Citer cet article

Larson, B. (2009). Mapping the Body and the Brain: Neurology and Localization Theory in the Work of Rodin. RACAR : Revue d'art canadienne / Canadian Art Review, 34(1), 30-40. https://doi.org/10.7202/1069498ar

\section{Résumé de l'article}

Cet essai tente d'interpréter les formes expressives des sculptures de Rodin à la lumière des modèles médicaux du cerveau et du corps qui commencent à circuler vers la fin du dix-neuvième siècle. Fondé sur la science neurologique, la théorie de la localisation stipulait que le cerveau se composait de sphères individuelles assumant des fonctions corporelles distinctes et que des canaux neurologiques spécifiques étaient reliés à ces zones particulières. La théorie de la localisation postulait que les activités du cerveau étaient compartimentées en se fondant sur la découverte que les deux côtés du cerveau n'étaient pas identiques. Se conformant à ces nouvelles théories, les figures de Rodin répondent à une multiplicité de stimuli internes, comme si diverses sensations, réactions et mouvements non totalement intégrés se produisaient simultanément. Alors qu'on doit à la neurologie la renaissance du concept du génie (artiste/poète) dément, le Penseur (artiste/poète) de Rodin adopte la posture emblématique de la mélancolie, traditionnellement associée à la fois au génie et à la pathologie. La théorie de la localisation et la neurologie ont servi de socle aux études sur les femmes hystérico-épileptiques menées par Jean-Martin Charcot. Dans Les Portes de l'Enfer de Rodin, juste en arrière du Penseur, on retrouve plusieurs figures de femmes damnées qui adoptent des postures associées à ce désordre.
Tous droits réservés @ UAAC-AAUC (University Art Association of Canada | Association d'art des universités du Canada), 2009
Ce document est protégé par la loi sur le droit d'auteur. L'utilisation des services d'Érudit (y compris la reproduction) est assujettie à sa politique d'utilisation que vous pouvez consulter en ligne.

https://apropos.erudit.org/fr/usagers/politique-dutilisation/ 


\title{
Mapping the Body and the Brain: Neurology and Localization Theory in the Work of Rodin
}

\author{
Barbara Larson, University of West Florida
}

\begin{abstract}
Résumé
Cet essai tente d'interpréter les formes expressives des sculptures de Rodin à la lumière des modèles médicaux du cerveau et du corps qui commencent à circuler vers la fin du dix-neuvième siècle. Fondé sur la science neurologique, la théorie de la localisation stıpulait que le cerveau se composait de sphères individuelles assumant des fonctions corporelles distinctes et que des canaux neurologiques spécifiques étaient reliés à ces zones particulières. La théorie de la localisation postulait que les activités du cerveau étaient compartimentées en se fondant sur la découverte que les deux côtés du cerveau n'étaient pas identiques. Se conformant à ces nouvelles théories, les figures de Rodin répondent à une multiplicité de stimuli internes, comme si diverses sensations, réactions et mouvements non totalement intégrés se produisaient simultanément. Alors qu'on doit à la neurologie la renaissance du concept du génie (artiste/poète) dément, le Penseur (artiste/poète) de Rodin adopte la posture emblématıque de la mélancolie, traditionnellement associée à la fois au génie et à la pathologie. La théorie de la localisation et la neurologie ont servi de socle aux études sur les femmes hystérico-épileptiques menées par Jean-Martin Charcot. Dans Les Portes de l'Enfer de Rodin, juste en arrière du Penseur, on retrouve plusieurs figures de femmes damnées qui adoptent des postures associées à ce désordre.
\end{abstract}

$A$ uguste Rodin's figure sculptures are powerful sensate beings whose bodies often convey extreme states of stimulation. He found his way through the example of Michelangelo, moving from Vanquished Man of the mid-1870s, criticized for its naturalism so perfectly realized that it was thought to have been cast from life, to the exaggerated figure of Adam done later in the decade (fig. 1). Early in 1876, Rodin travelled to Italy in the immediate aftermath of the 400th anniversary (1875) of Michelangelo's birth and studied his paintings and sculptures. According to Rodin, "When I went to Italy...I had my mind full of Greek models.... At every turn, Michelangelo's figures contradicted the truth I thought I had finally acquired.... Why this incurvature of the torso? Why this raised hip? Why this lowered shoulder?"' While it may seem that the Baroque qualities of Michelangelo's figures led Rodin away from naturalism and the true, living body, he in fact drew closer to current medical models that probed and mapped the body's substructures. Rodin's deepening interest in the workings of the body corresponded with a growing current of scientific naturalism in France, a trend promoted within the sciences and in officially backed Naturalist art by a new Republic that equated progress with biological and technological advances.

Like many of Michelangelo's sculptures such as Day from the Medici tomb in Florence, which Rodin had sketched, his Adam twists with torso in opposition to the lower body. The figure is just coming to life, still in a state of awakening consciousness. Adam's fully developed muscles are in various stages of response to his new condition, put into motion by a single spark of life. The head lolls to the left while the torso twists to the right; the left arm hangs nearly limp like that of the dead Christ in Michelangelo's Pietà, while the other begins to contract. The figure's extended index finger of the right arm is reminiscent of Michelangelo's Adam from the Sistine ceiling being given life through divine encrgy. But a spark that stimulates nervous encrgy has sources in the medical world as well, as does a body constituted of differing levels of energy and reaction. The disproportionately large extremities, especially the hands and feet, of Rodin's male figure arc not just a pastiche of examples by Michelangelo, but serve to call attention to the systems at work in the body.

Rodin had been familiar with newly emerging medical concepts of the body since the mid-1860s when he took classes in myology, neurology, and osteology at the Écolc de Médecine. ${ }^{2} \mathrm{He}$ also sketched corporeal deformities at the nearby $\mathrm{Mu}$ sée Dupuytren, a medical museum of human anatomy, used as a teaching tool of the École. ${ }^{3}$ At this time, the École was distinguished by a faculty considered so controversial for its devotion to materialist explanations of human bchavior that it was subject to censorship. ${ }^{4}$ Among the prominent scientists was Paul Broca, whose work on locating the area of speech in the brain (1861) was still a sensation when Rodin was there. The neurologist Jules Bernard Luys, attached to the École, published his findings on the connection between nerves of the spinal and cerebral system in his Recherches sur le système nerveaux cérébrospinal in 1865. His work on pathways of nervous energy was part of the accumulating evidence that the nervous system had distinct corridors attached to spccific areas of the brain. The neurologist Alexander Axenfeld, whose later work on the modern nervous system as depleted of energy would find its ultimate expression in his celebrated and influential treatise Traité des névroses (1883), taught at the École in the mid-1860s. Neurology became a focus of medical pathology in the second half of the nincteenth century; neurological disorders were used to explain a range of illnesses from epilepsy to paralysis to negative transgenerational heredity and psychological ills.

Rodin's interest in neurological disease has been investigated to some extent by Debora Silverman in her book Art Nouveau in Fin-de-Siecle France (1989) and by medical practitioners who have examined the artist's many individual hand sculptures, a number of which are deformed by nerve disorders. ${ }^{5}$ It may be as 


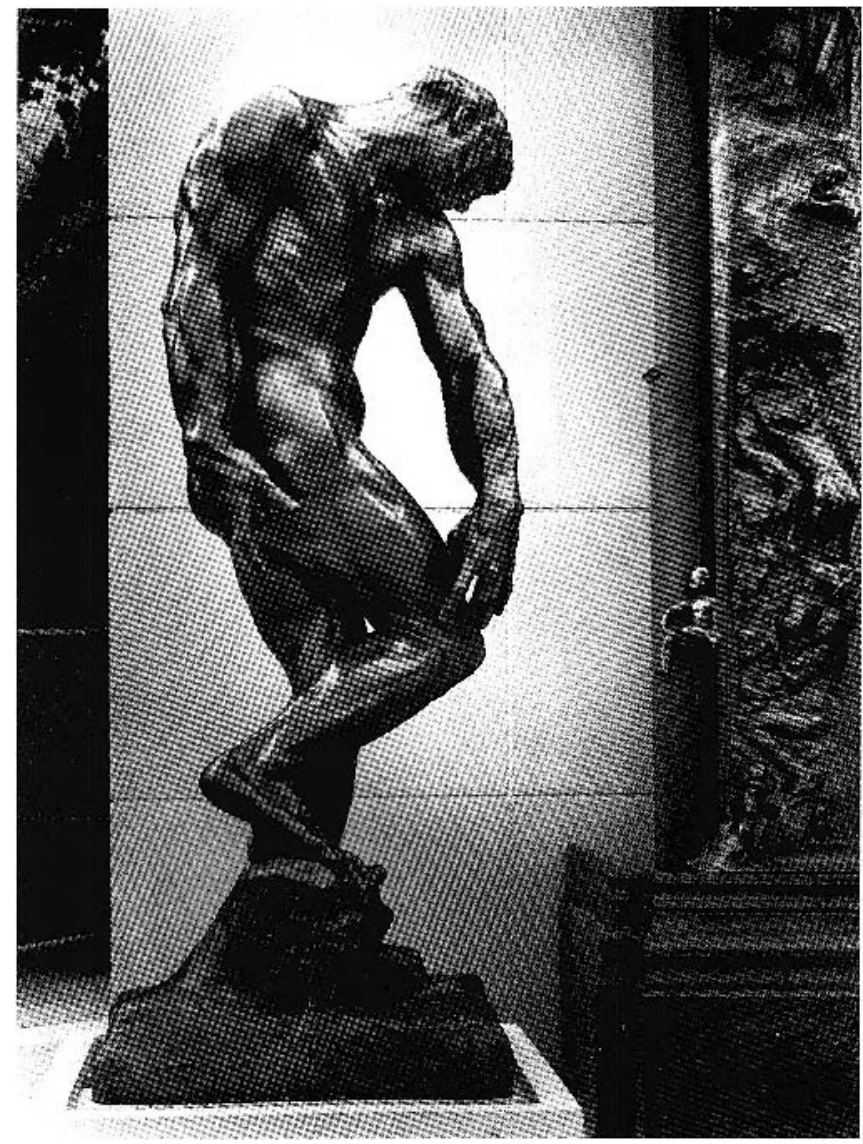

Figure I. Rodın, Adom, 1877-79. Bronze, cast Georges Rudier I oundry 1974, 11/12, 191.8 × 74.9 ×74.9 cm. Iris \& B. Gerald Cantor Center for Visual Arts at Stanford University, Gift of Iris and B. Gerald Cantor. 1985.15 (Photo: Frank Wing)

early as the mid-1860s that Rodin began his sculptural inventory of expressive, distorted hands. Examples like these could be studied at length at the Dupuytren. Although information about the trip to Italy is limited, Rodin may have been encouraged further in this direction a decade later through the example of La Specola, a medical museum in Florence dating back to the eighteenth century, in which wax examples of individual and sometimes pathological body parts were on display. Among the more dramatic of the hands deformed by ncurological problems is Rodin's Large Clenched Left Hand (ca. 1885, fig. 2), an example of paralysis of the median and cubital nerves of the wrist. ${ }^{6}$ Rodin's one-time secretary and long-time admircr, poet Rainer Maria Rilke, may have had such a hand in mind when he remarked that among the many sculptures of hands by Rodin there are thosc that arc "criminal hands, tainted with hereditary disease." Anti-social behavior and heredity were perceived to be bound up with neurological disorders at the end of the

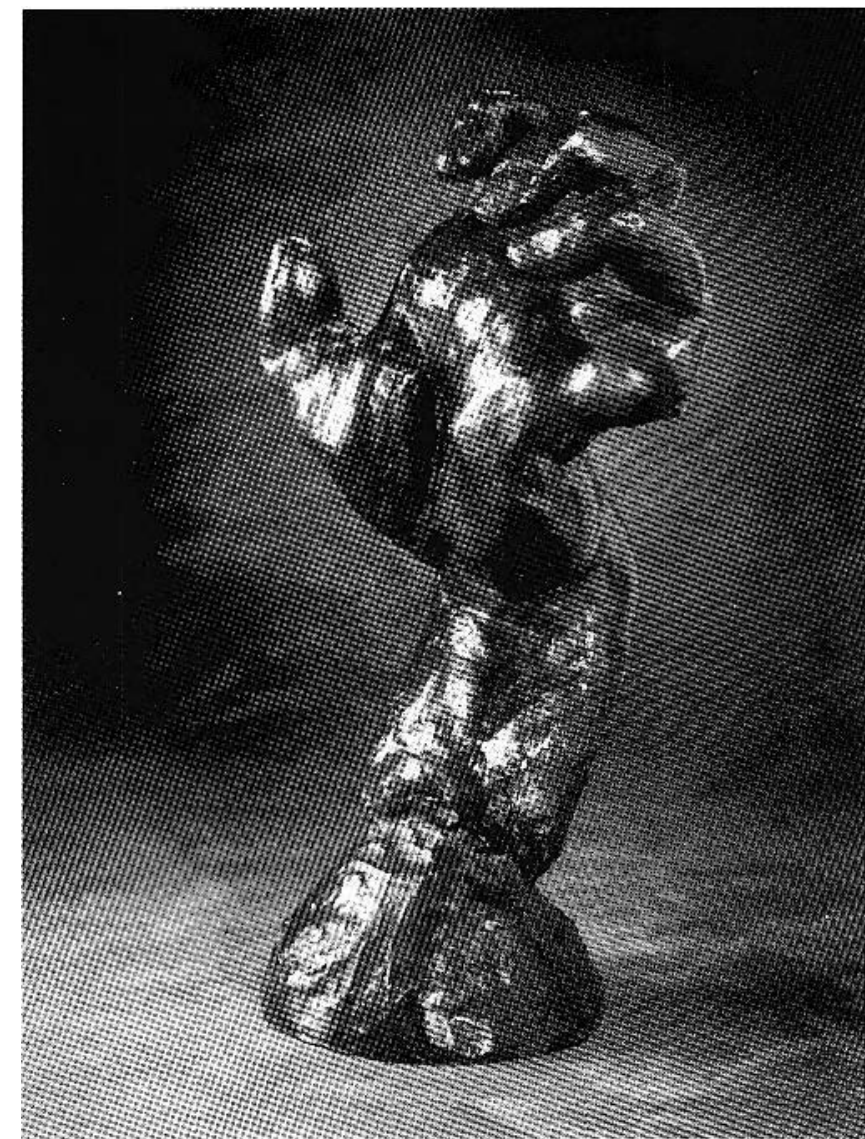

Figure 2. Rodin, Largc: Clenched Left Hand, ca. 1885, Bronze, cast Georges Rudier Foundry 1966, 3/12. 46.4 × 26.4 × $19.3 \mathrm{~cm}$., signed A. Rodin and inscribed (C) by Musée Rodin 1966. Irıs and B. Gerald Cantor Foundation (Photo: Steve Oliver)

nineteenth century. Some of Rodin's individual hands seem to have been modclled for use on certain sculpturcs; others were exhibited as works in their own right, as was the casc with Large Clenched Left Hand; and still others were part of a vast inventory for study.

Electricity was identified as the agent that flows through the nerves, communicating with muscles through electronic impulses. In turn, electric shocks were used at mid-century both to map muscle and nerve response and for therapeutic purposes where pathological conditions were identified. 8 GuillaumeBenjamin Duchenne de Boulogne was a pioneer in electrical diagnoses and therapy, publishing in 1855 his De l'electrisation localisée et de son application à la pathologie et à la thérapeutique, followed in 1862 by Mécanisme de la physionomie humaine: Analyse électro-physiologique de l'expression des passions applicable à la pratique des arts plastiques. In Mécanisme de la physionomie humaine the scientist mapped the face through electrical stim- 


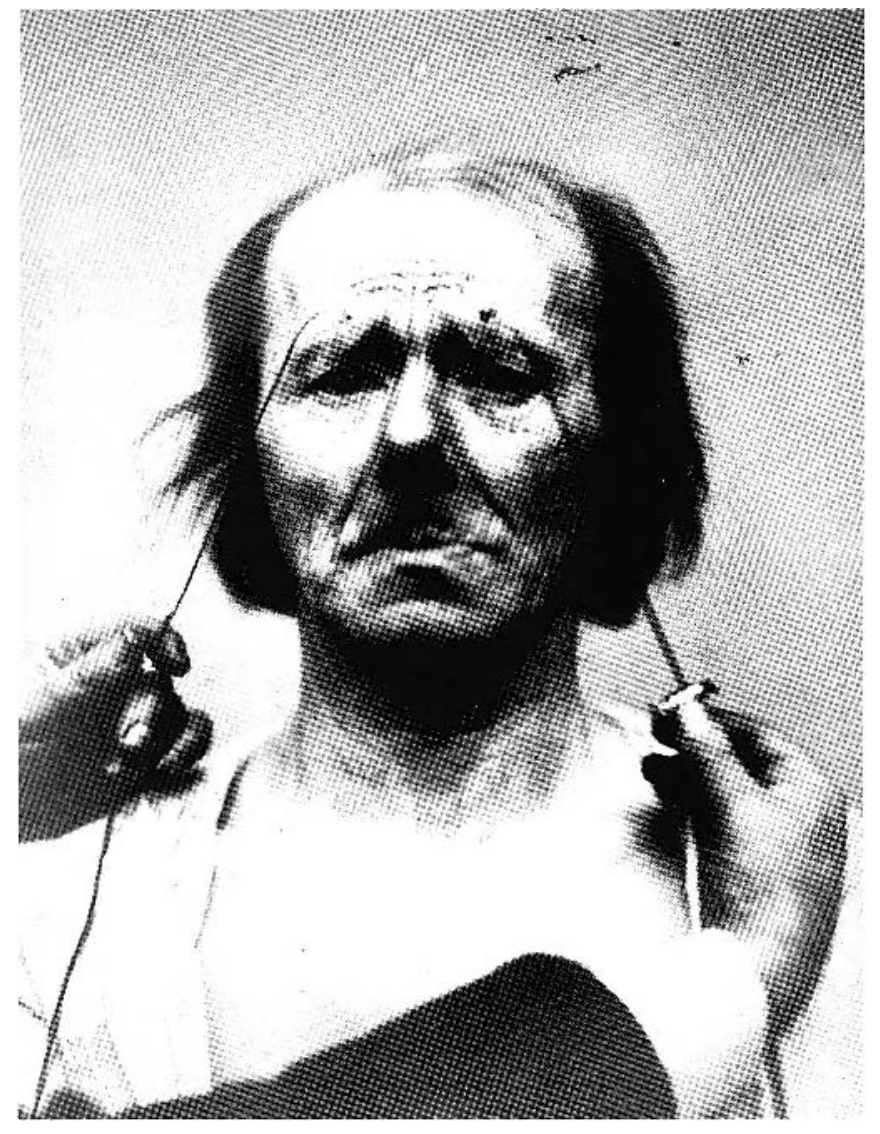

Figure 3. G.-B. Duchenne de Boulogne. Mécanısme de la physionomie humanıne; où Analyse electro-physiologique de l'expression des passions (Parıs, 1862), figure 20.

ulation, demonstrating that all emotions made use of specific facial muscles. He illustrated this publication with dozens of photographs. This work was so influential that examples were appropriated and used for illustration in Charles Darwin's The Expression of the Emotions in Man and Animals (1872). Certain of Rodin's expressive physiognomies appear to demonstrate familiarity with the work of Duchenne de Boulogne. For example, his Monumental Head of Pierre de Wissant, depicting a doomed burgher of Calais who prepares for death, follows Duchenne de Boulogne's contention that contraction of the brow muscles produce the effect of "profound suffering, with resignation" (figs. 3, 4).?

Electrophysiology of the nervous and muscular system was taken up in the mid-1860s by Étienne-Jules Marey, an inventor of highly imaginative machines to determine internal corporeal activity. These included his "myographs," or instruments to measure muscle contractions. Rodin may have been familiar with his

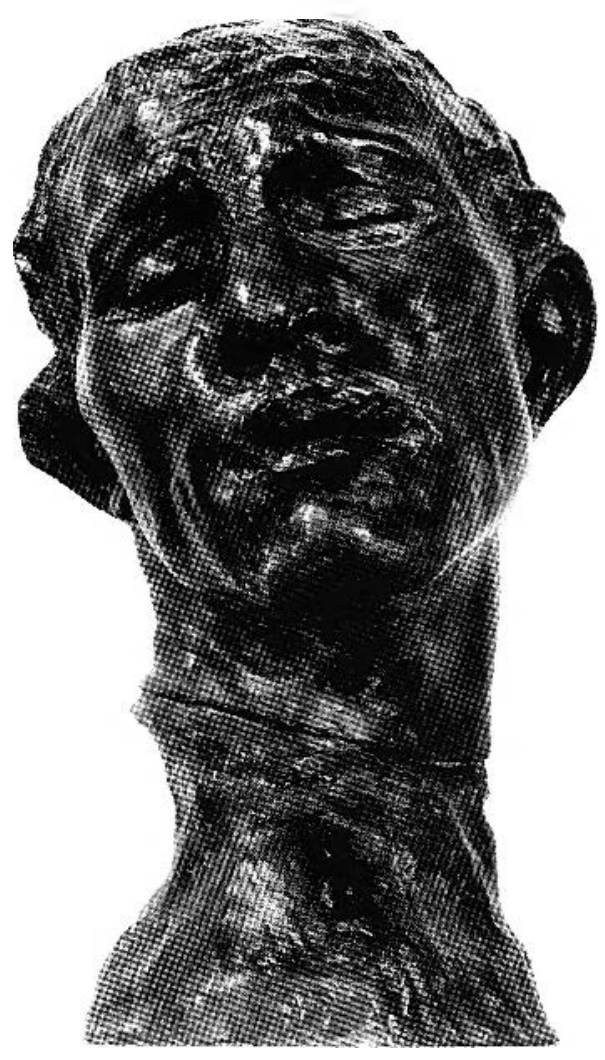

Figure 1. Rodin, Monumental Head of Pierre de Wissant, 1886 -87, enlarged ca. 1909. Bronze, cast Suse Foundry 1969, $92.7 \times 26 \times 24 \mathrm{~cm}$. Iris and B. Gerald Cantor Center for Visual Arts at Stanford University, gift of the Iris and B. Gerald Cantor Foundation, 1971.118 (Photo: Frank Wing).

early work on muscles, for Marey published in the Journal de l'anatomie, edited by Charles Robin, a prominent lecturer at the École de Médecine when Rodin was taking classes there. ${ }^{10}$ Marey's rescarch would be popularized in his La machine animale, published in 1873. His interest in documenting the activity of the body was such that after 1870 he began to distinguish himself with his motion studies, in which he used chronophotography and graphic means to observe what the eye could not see: corporeal movement, broken down into discrete split-second positions. Rodin's figures also are often in motion. While the artist claimed not to like high-speed photographs because no single frame captures the unfolding of a movement, he nevertheless subscribed to Eadweard Muybridge's Animal Locomotion in 1887, which has many parallels to the work of Marey. " Albert Elsen has noted that Walking Man (1899), for example, may have been influenced by Marey's photographs of a man in motion from a protocinematic series of athletes of the 1890s (fig. 5).12 
Rodin's hand sculptures were just one aspect of the artist's deconstruction of the body into separate, expressive parts. By the late 1870 s, Rodin began to work in a manner that was unique during this period: he modelled individual body parts in clay or plaster that could be conjoined in a variety of ways (or used as separate artistic statements). The process was additive, resulting in partial or total figures that, likc Frankenstein's monster where body parts from various figures were somehow held together, ultimately conveyed a sense of the tragic. Until recently, the partial figure Walking Man (1899) was thought to be a study for St. John the Baptist Preaching (1878), although it is now recognized that this sculpture was created some two decades later, and is comprised of two studies related to St. John the Baptist Preaching, a torso and a reworked pair of legs. The lack of continuity between legs and torso can be observed in a slight disjunction at the hips and a torso that is somewhat small for the thick, muscular legs. While Rodin has been credited with the modern innovation of partial figures and individual body parts as unique artistic expressions in their own right, his experiments in this direction began at a time when anatomists, neurologists, and myologists were at work breaking down and compartmentalizing the body in an attempt to understand the independent action of individual components. The ultimate expression of this work would be found in localization theory, a hypothcsis popular in the last few decades of the nineteenth century that posited the brain itself could be mapped into separate regions that in turn were master keys for physiological functions likc language, feeling, movement, a variety of abilities, and even sight. Philosophically, the attempt to assign individual sites for various mental, motor, and sensatc functions was met with rcsistance by those who perceived localization theory as an attack on the soul, now broken up into different areas of the brain. ${ }^{13}$

Before the 1860s, scientists had believed that while lofticr functioning might be housed in the brain, it was the spinal chord that served sensory and motor functions. Building on the work of Luys and other neurologists, motor and sensory ccnters were also ascribed to the brain after the mid-1860s. The neurological system with its ultimate connection to brain loci was now thought of as being so sensitive to external stimulation that impressions associated with touch and visual and aural stimulation werc considered as powerful as any conscious decision-making regarding accumulated knowledge of the world. Research positing the compartmentalization of the brain into distinct units with specific expressions and functions responding to stimuli would not have been lost on an artist concerned with representing the true living body.

Localization theory was sometimes called "the new phrenology" and it does have roots in the work of ncuroanatomist and founder of phrenology Franz Joseph Gall. Gall believed that the brain was divided into separate regions that were responsible

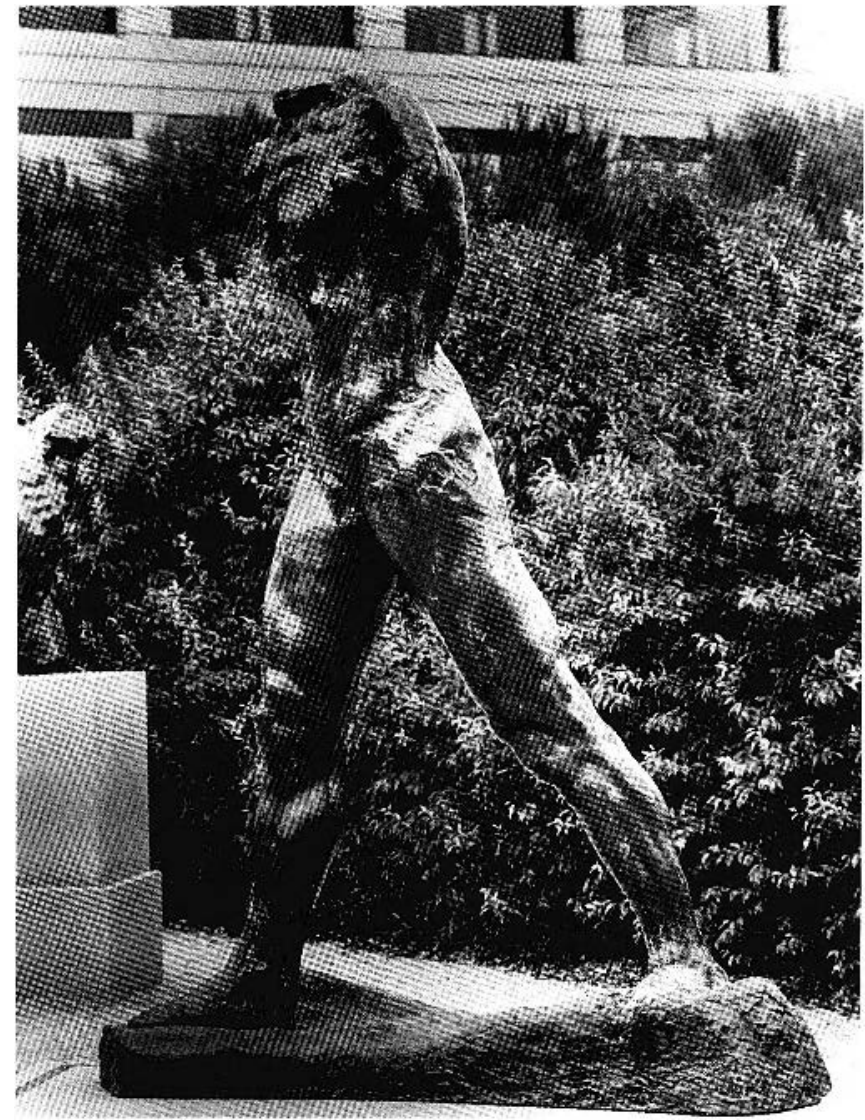

Figure 5. Rodin. The Walking Man, 1899/1900, enlarged 1905-07. Bronze, cast Georges Rudier Foundry 1970, 12/12, $223.2 \times 74.9 \times 134.9 \mathrm{~cm}$. Iris \& B. Gerald Cantor Center for Visual Arts at Stanford University, gift of B. Gerald Cantor, 1982.306 (Photo: Frank Wing). This sculplure is dedicated by Iris Cantor to honour and celebrate Stanford University President Gerhard Casper's leadership and role in rebuilding the Cantor Arts Center, August 31. 2000.

for individual functions of the body. $14 \mathrm{Phrcnology}$, in which human characteristics arc related to individual bumps on the cranium itself, was a dimension of Gall's work that held popular appeal, yet was somewhat distinct from the notion of different internal organs within the brain that were related to functions of the body. Nevertheless, the lay public understood localization theory as a historical devclopment from phrenology. Rodin maintained an interest in the pseudo-science of phrenology. As the writer Caroline Rémy recalled of her sessions with Rodin, "He would feel your skull as a phrenologist would... and grow ecstatic over this bump and that onc." 15 On other occasions Rodin would compare his models' heads with various animals, an allusion to still older models of human character as it relates to the features of animals. 16 

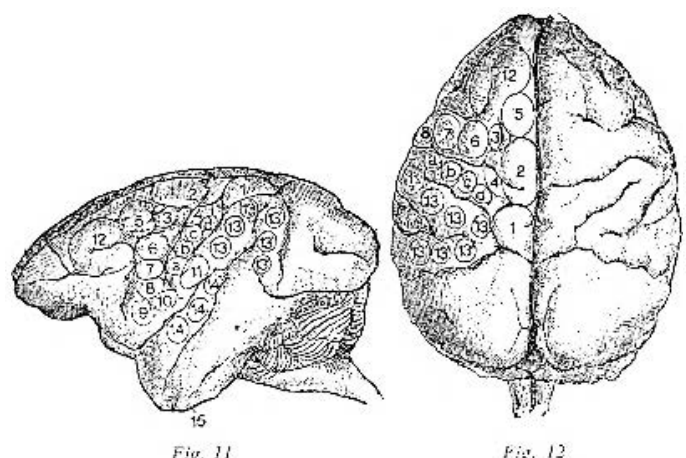

Fig. 11. Face externe du cerveau du singe
Les centres d'excitation électrique sont indiqués sur les figures par des cercles ou régions qui délimitent l'étendue de la surface qui. stimulés. produisent certains mouvements déterminés :

1 : le membre postérieur opposé s'avance comme pour marcher

2 : mouvements complexcs de la cuisse, de la jambe et du pied

3 : mouvements de la queue

: rétraction avec adduction du bras opposé

5 : extension en avant du bras et de la main opposéc. Cercles a. b.

d: mouvements individuels et combinés des doigts et du poignct

6 : supination et flexion de l'avant-bras

$7:$ action des zygomatiques

: élévation de l'aile du nez et de la lèvre supérieure

9 : ouverturc de la bouche avec extension au dehors

10 : rétraction de la langue

12 : rétraction de l'angle opposé de la bouche

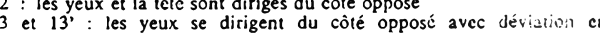

haut ou en bas

pposé

15: torsion de la lèvre et de la narine du même côté.

FERRIER (D.), Les fonctions du cerveau, trad. fr. Paris. J.-B. Baillèrc, 1878

Fig. 12. Surface supéricure du cerveau du singe.

FERRIER (D.), op. cit.

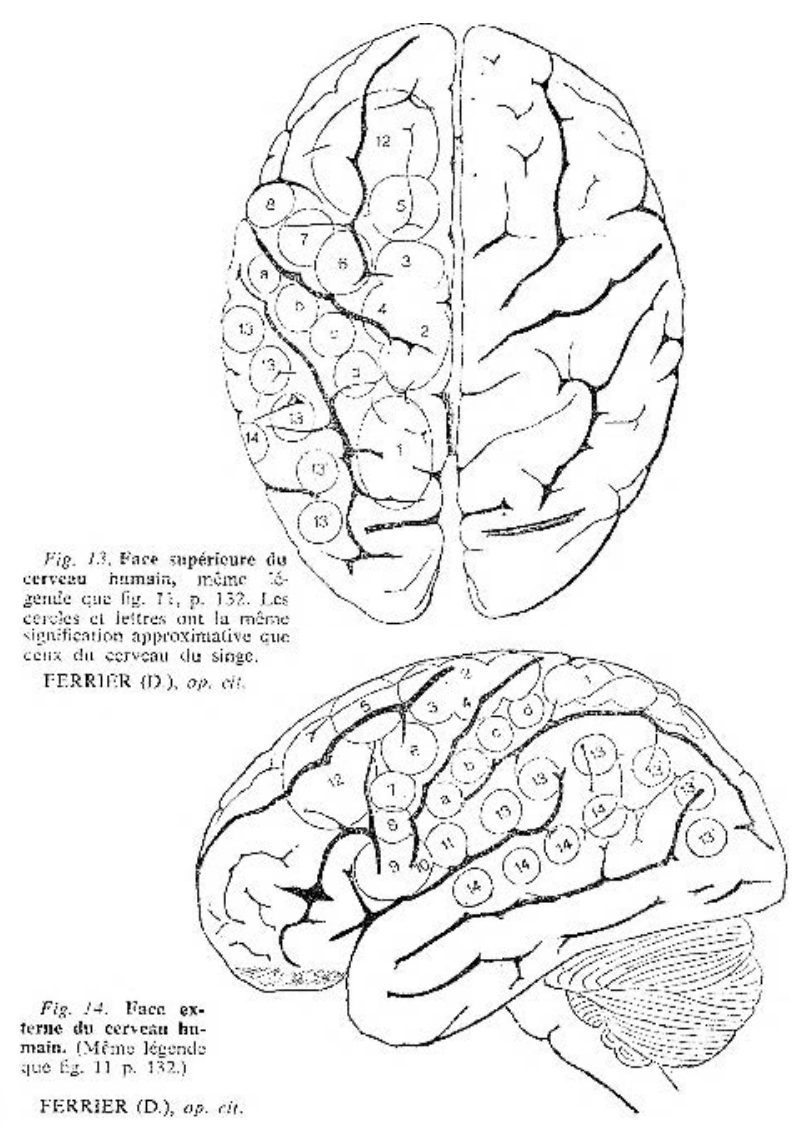

Figure 6. D. Ferrier. Functions du Cerveou (Paris, 1878). figs. II 14

Until Gall's time and then after the turn of the century, the brain was thought to act as a whole, a single unit without physiological division. 17 Even after Gall's death, in 1828 the prominent physiologist Jean-Pierre Marie Flourens diverted attention away from the idea of a brain with many different faculties. However, Gall's ideas were carried on by Jean-Baptiste Bouillaud, Dean of the Faculty of Medicine until 1862, and thereafter President of the Academy of Medicine. His interest in the connection between loss of speech and lesions in specific area of the brain (the anterior lobes) paved the way for Paul Broca. Bouillaud's son-in-law Ernest Auburtin was an important localization supporter at mid-century who argued that all sensory and corporeal functions would eventually be found to be tied to specific centers in the brain. He was present at a series of meetings sponsored by Broca in 1861 at the Anthropological Society of Paris when Broca convinced the scholarly community that speech resided at one particular site in the anterior lobes, a major coup for localizationists. ${ }^{18}$ Broca's work, which was supported by the discovery of brain lesions that suppressed speech, also demonstrated that the two halves of the brain were not identical in function. Asymmetry studies accumulated in the seventies and eighties, with the right side of the brain emerging as the "dark" creative side, responsible for sensibility and emotion, while the left side was found to house voluntary, intellectual functions, including speech. 19 It was also known that the left side of the brain was tied to the right side of the body and vice versa. Thus, one might consider Rodin's interest in strong contrapposto poses, especially in his male figures like Adam, in this light. The body, broadly speaking, was split in half, its two sides working somewhat in opposition to one another. Intellectual versus emotional capacities were also somewhat disjunctive, functions of different sides of the brain. The body's physical, unalterable constitution, it might be argued, was responsible for tragic aspects of the human condition. 
David Ferrier's work consolidated the research of the 1860s and pushed discoveries further in the direction of materialism. His important and influential The Functions of the Brain of 1876 was translated into French in 1878. Through electric currents applied directly to the brains of monkeys and other animals, Ferrier mapped specific locales of the brain in tcrms of control of sensation, language, motion, and feeling that he then applied directly to humans (fig. 6). The "mind" or human psychology was merely the result of brain functioning, and mental abilities like languagc were the subjective side of the sensory-motor strata of the brain.

By the time of Ferrier's publication in book form, localization theory was widcly accepted in France. The body and brain as holistic entities had been shattered into dozens of individual components. Rodin's figures respond to a multiplicity of internal stimuli. As Rainer Maria Rilke described Rodin's figures, "[The surface of the body] consisted of infinitely many movements. The play of light upon these surfaces made manifest that each of these movements was different and each significant. At this point they seemed to flow into one another; at that, to greet each other hesitatingly; at a third, to pass by each other without recognition, like strangers." 20

Certain of Rodin's figures were further complicated by being pressed up against one another, forced by proximity and association to intcract even if that was not the original purpose of the figures; thus, they ultimately belong in their own worlds, and we might say within this individual world discrete body parts follow distinct rather than holistic expression. This is the case with the contorted Crouching Woman, eventually affixed to the figure of Falling Man, conceived independently then joined in I am Beautiful (fig. 7), or The Prodigal Son, added to the figure of a woman who slips past him, suggesting that he perpetually seeks his beloved, in Fugit Amor. In such figures, there is no sense of ultimate resolution or peace. To an audience in the late nineteenth century, aware of current scientific and rcligious theories regarding the division of soul from the body, thcy may have represented the material body of scientific experiment that lacks the unifying grace of the holistic soul.

The many figures in Rodin's Gates of Hell (1880-1900), a sculptural portal loosely based on Dante's Divine Comedy, were a virtual seedbed of idcas for recomprised figures. The figuresdamned for giving in to carnal drives-suffer ultimate loneliness and alienation from spiritual values. In Rodin's work hell is found within, in the passions that are expressed through the nervous and muscle systems. Rodin's friend, the critic Gustave Geffroy, called Rodin the "veritable and great historian of neurosis of this century." 21

Contemporary ideas regarding neurology and myology may also account for the appearance of the famous Thinker at top center of The Gates. Emphasizing greater compression,

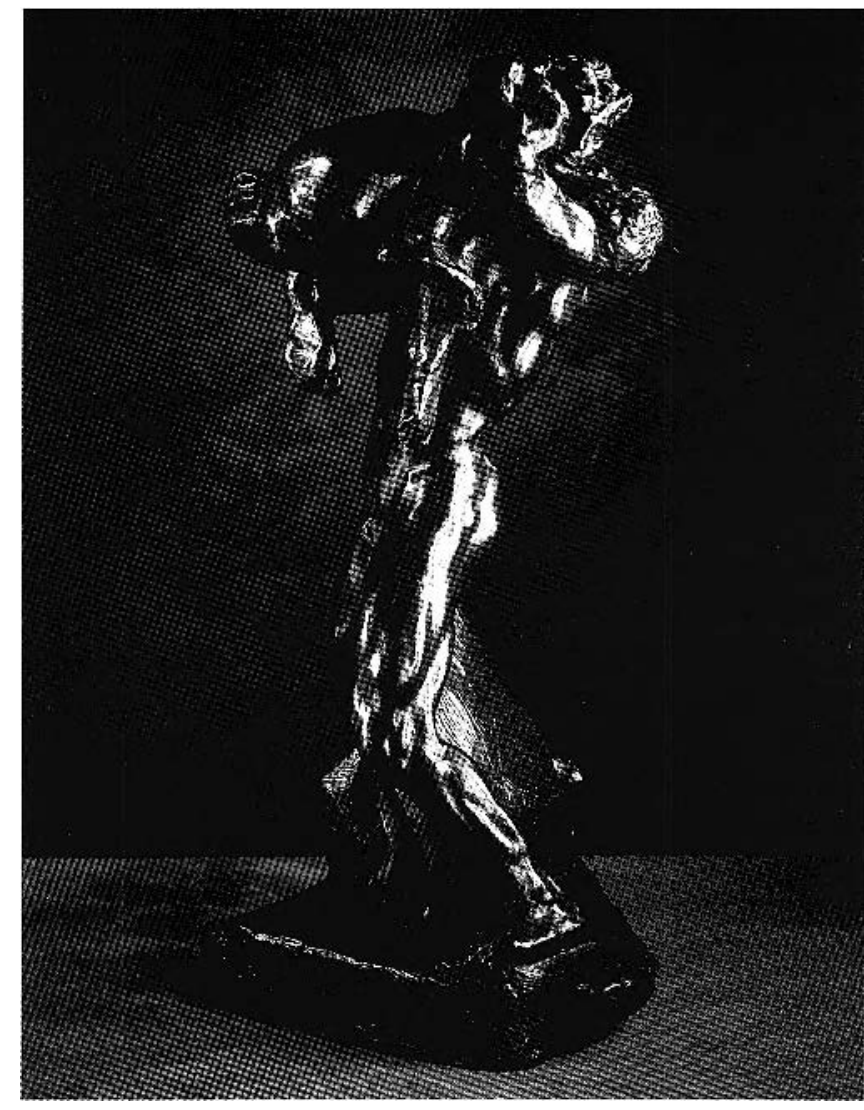

Figure 7. Rodın, I am Beoutiful, before 1886. Bronze, date of cast unknown, Alexis Rudier Foundry, $70.5 \times 30.5 \times 31.7 \mathrm{~cm}$., signed and stamped inside with raised signature $A$. Rodin and inscribed Alexis Rudier Fondeur Poris and the following quotation from Charles Baudelaire's Les Fleurs du mal:

$$
\begin{aligned}
& \text { Je suis belle o mortels. comme un rêve de Pierre } \\
& \text { Et mon sein où chocun s'est meurtri tour à tour } \\
& \text { Est foit pour inspirer au poète un omour } \\
& \text { Eternel et muet oınsı que la motière }
\end{aligned}
$$

Iris and B. Gerald Cantor Foundatıon. Promised gift to the North Carolina Museum of Art (Pholo: Steve Oliver).

he nevertheless sits in the classic pose of melancholia, elbow on knee, fist to face, exemplified by Dürer's Melencholia I (figs. 8, 9). In 1888, The Thinker (originally Dante) was exhibited as a single figure with the title The Poet and, in 1889, The Poet-Thinker. Thus, he seems to become more gencrally the artist or the solitary genius, perhaps Rodin himself. Rodin said this of The Thinker:

The thinker has a story. In the days long gone by, I conceived the idea of the Gates of Hell. Before the door, seated on a rock. Dante thinking of the plan of his poem. Behind him, Ugolino, Francesca, Paolo, all the characters of the divine 


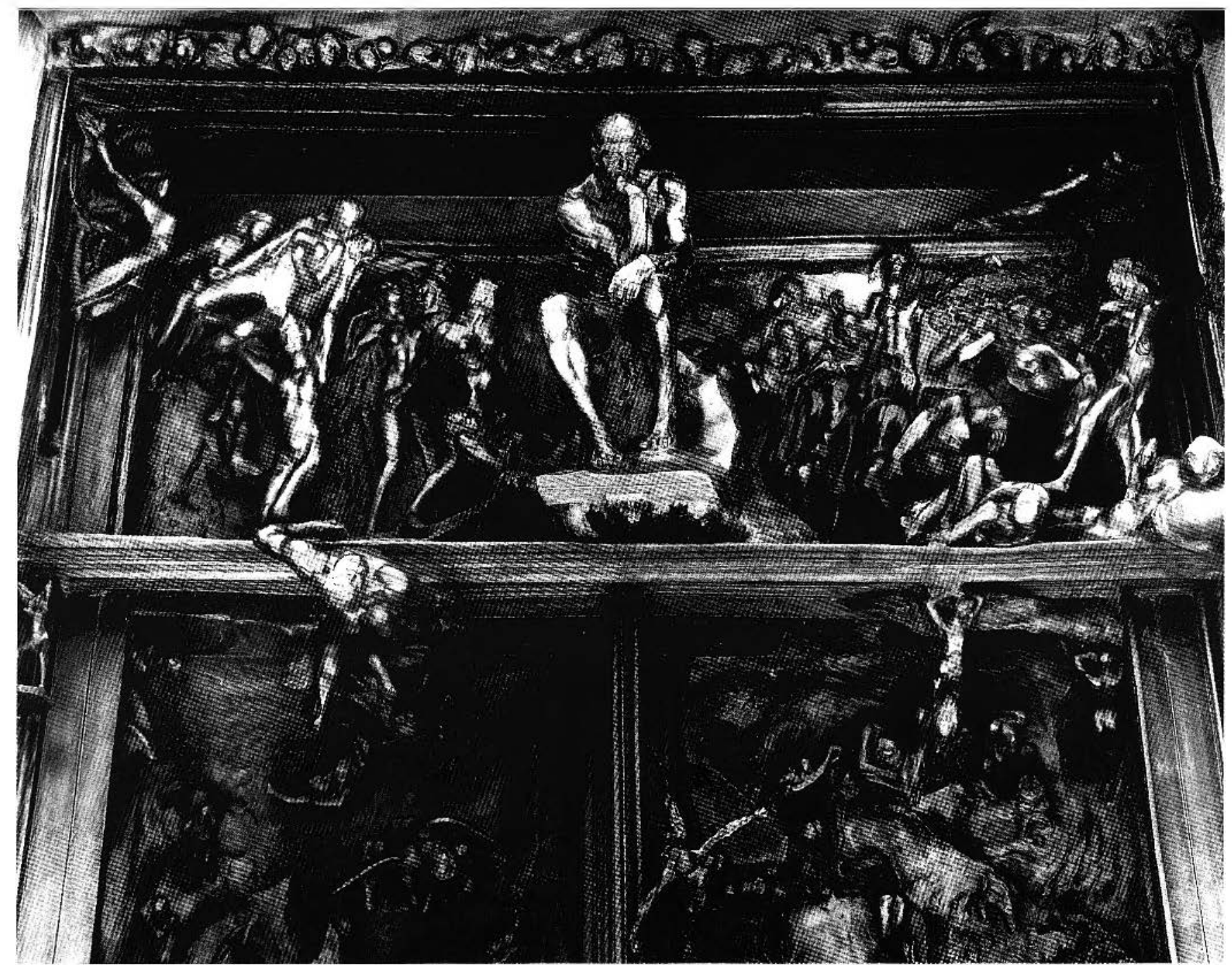

Figure 8. Rodin, detall from The Gotes of Hell. Bronze, Coubertin Foundry, no. 5; posthumous cast authorized by Musée Rodin, $1981.636 .9 \times 40.1 \times 84.8 \mathrm{~cm}$. Stanford University Museum of Art, 1985.86 LI.12.84. Gift of the B. Gerald Cantor Collections (Photo: Frank Wing).

comedy. This project was not realized. Thin ascetic Dante in his straight robe, separated from the whole world would have been without meaning. Guided by my first inspiration I conceived another thinker, a naked man, seated upon a rock, his feet drawn under him, his fist against his teeth, he dreams. The fertile thought slowly elaborates itself within his brain. He is no longer the thinker; he is the creator. ${ }^{22}$

The classic attitude of melancholy was originally based on the iconic posture of mourning during antiquity, but by the medieval period it came to represent insanity. Melancholia, identified with the element earth, was thought to be one of the pathological states of an imbalance of the humours, namely black bile, an idea that can be traced back to medical theories of ancient times. Melancholia had also been associated with the artistic temperament from the time of Dürer on. The idea that mental illness and artistic creativity went hand in hand gained renewed interest in the late nineteenth century; Cesare Lombroso's Man of Genius (1863) popularized the topic in a new modern scientific sense in the second half of the century. In the decades to follow, the artist, particularly the artist who practised modern styles, was thought by many to be one of the "degenerates" that lurked on the periphery of society. In the late nineteenth century, artistic melancholia was connected to nervous 
disorder. Rodin's close friend, the poet Maurice Rollinat, was a diagnosed neurasthenic. His poetry, including Les Névroses (1883), builds upon the myth of the artist tormented by his own neurological system. As Rodin did in The Ciates of Hell, Rollinat united themes of damnation with modern ncurosis. ${ }^{23}$

Rodin may have taken direction from another source as well. In Florence he had visited the Medici chapel, wherein Michelangelo had produced a sculpture of Lorenzo de Medici: hand to chin, his face in shadow, he too is in the traditional pose of the melancholic. Rodin identified Michelangelo himself as a melancholic: "Michelangelo is only the last and greatest of the gothics, the turning of the soul upon itself, suffering, a disgust with life, struggle against the chains of matter....[He] himself was tortured by melancholy." 24 By the 1880s, when The Thinker came to fruition, the mind that thinks was regarded as the subjective side of the brain that deploys its various controlling components, pathological and otherwise, over the body. Rodin's Thinker contracts: right elbow crosses to left knee; legs are drawn under the body; toes tightly grip the base; tendons, nerves, and muscles strain against the skin.

The leading neurologist of the last decades of the nineteenth century was Jean-Martin Charcot, whom Rodin appears to have known as he was close to Charcot's stepdaughter and attended her wedding in 1887. Charcot was a professor of pathological anatomy at the École de Médecine in the 1870 s and was then given a chair of nervous diseases in 1882. Influenced by Duchenne de Boulogne, Charcot made use of electrodiagnostic testing whereby patterns of response indicated types of diagnoses. Charcot associated nervous disorders with real physical alterations; at first he sought disease in lesions of the spinal chord, but under the influence of localization theory, by the early 1880 s, he came to believe that lesions would be found ultimately within the brain itself. 25 Charcot had started systematically studying cerebral localization in 1875 and taught a course at the École de Médecine specifically on this topic in that year.

Charcot's work on the nervous system led him to study the mainly female patients at the Salpêtrière Hospital who were thought to be "hysterics." Like Duchenne de Boulogne, Charcot used photography in his medical work. Photographs of his patients were published, beginning in 1877 with the first of the three-volume series Iconographie de la Salpêtrière. Along with his popular open teaching sessions, these publications made hysteria publicly known. Hysteria included a variety of mysterious symptoms, including paralysis, muscle contractions, partial blindness, mutism, and anorexia. In severe cases, hysteria resulted in violent seizures that mimicked those of epilepsy. In 1881, at a time when there were more than 5,000 women diagnosed with hysteria at the Salpêtrière, Charcot's colleague and collaborator Paul Richer published his important and richly illustrated

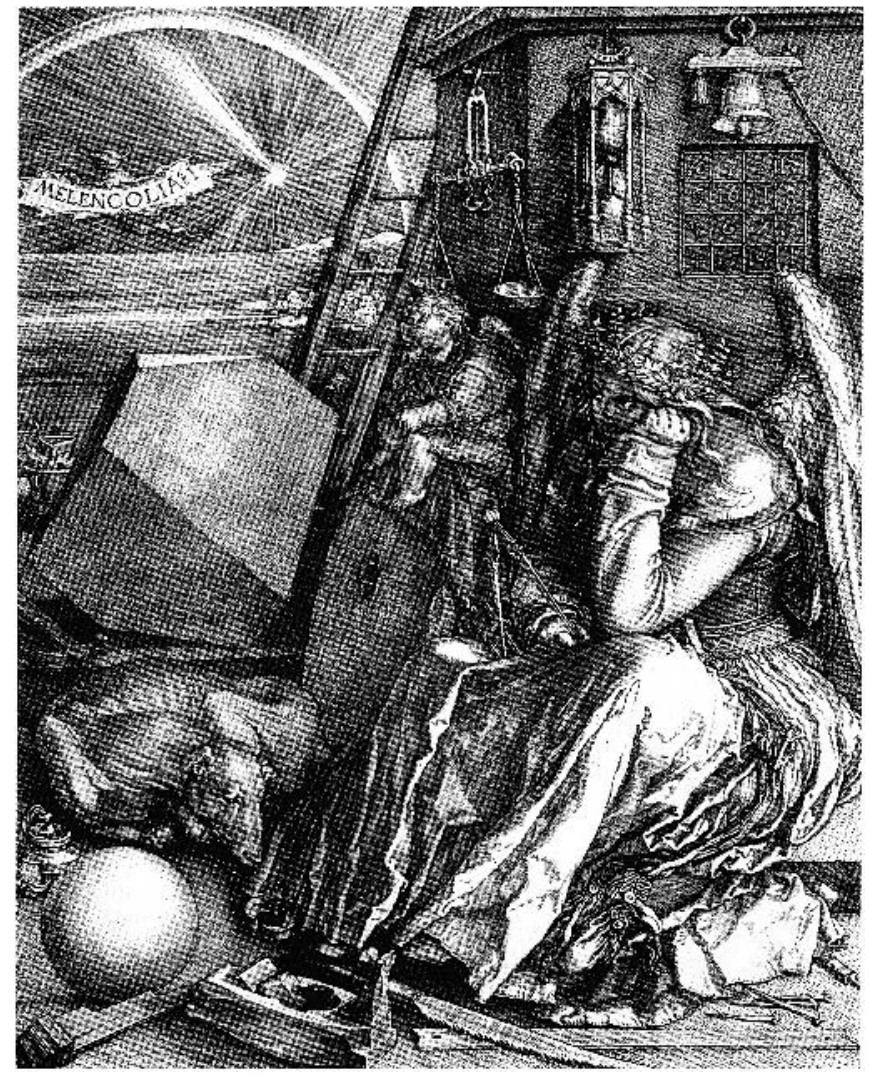

Figure 9. Albrecht Dürer, Melencholia I, 1514. Engraving, $23.7 \times 18.7 \mathrm{~cm}$. Kupferstichkabinett, Staatliche Museen zu Berlin, Inv. B.74-II. Berlin, Germany (Photo: Joerg P. Anders).

Etudes Cliniques sur la Grande Hystérie ou Hystéro-épilepsie. Here he laid out the four-fold stages of the attacks he and Charcot had come to believe characterized hysteria (fig. 10). Stages one and four consisted of the onset of seizure and final dissolution into delirium, respectively. The second and third are of greater iconographical interest: the second was identified as "clownism," in which women took on acrobatic poses, and the third was identified by attitudes passionnelles, in which postures of religious fixation were assumed (as in a crucifixion pose). Certain of Charcor's patients claimed to be saints, martyrs, or even possessed. This intriguing aspect of his hysterics led Charcot to examine medieval representations of saints undergoing extreme circumstances or of the possessed whom he believed to have actually been hysterics. He and Richer published Les démoniaques dans l'art on this subject in 1887.

By the 1880 s, Rodin began to concentrate largely on female figures, many of which assumed "hysterical" poses. Examples are to be found among the damned in The Gates of Hell. To 


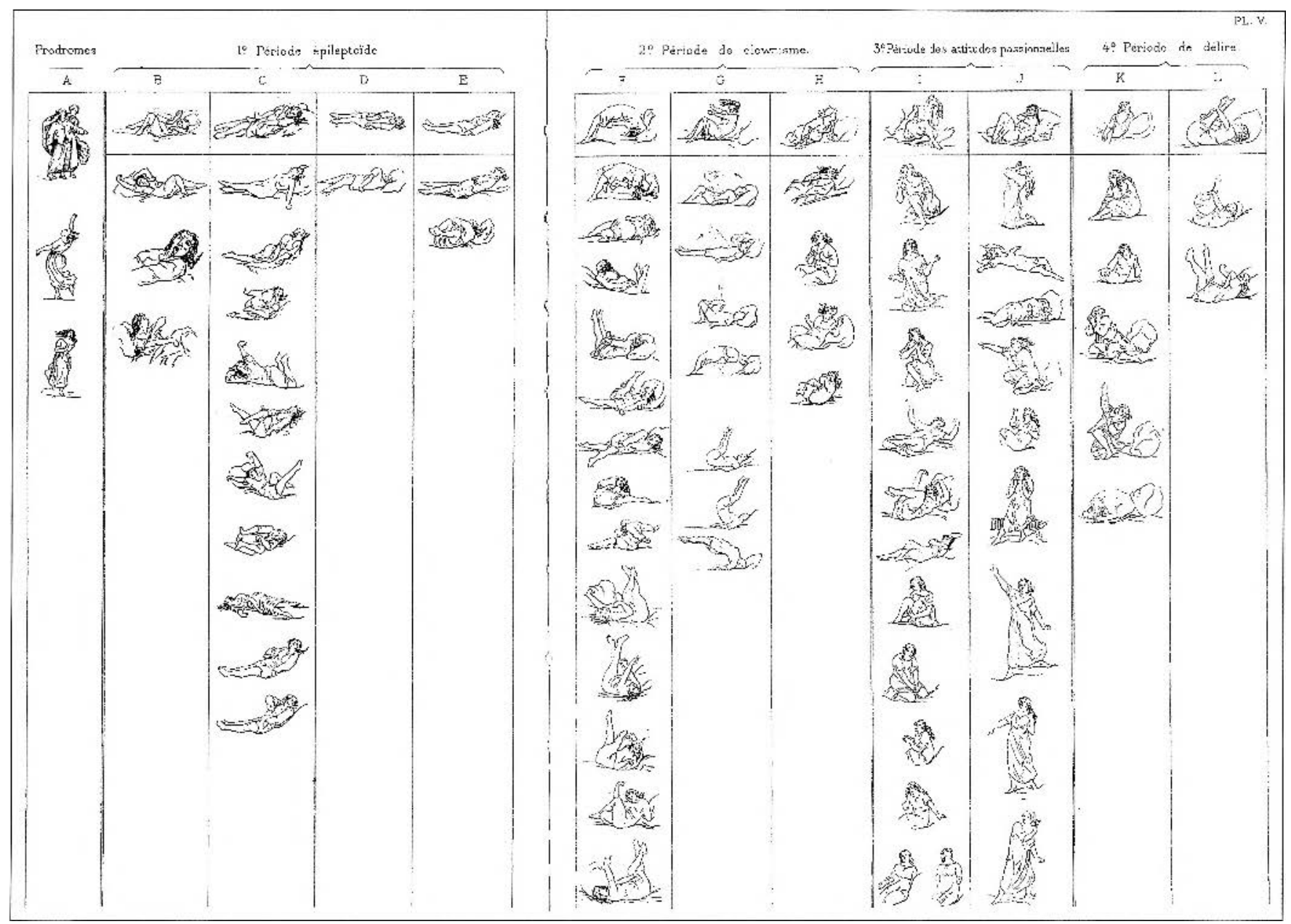

Figure 10. Richer, Tablcau synoptique de la "grande attaque hystérıque complète et régulière," avec posıtıons typiques et "variantes," Études Cliniques sur la Grande Hystérie ou Hystéro-épilepsie (Paris, 1881). pl. V.

the left and right of The Thinker are suffering stiff-limbed female figures that may allude to hystero-epileptic attacks. A Damned Woman, also existing as an individual study, was added to The Gates after 1887 (fig. 11).26 She rises up, touching the ground beneath a shoulder. Her legs contract and her arms are thrown stiffly in one direction; her left hand appears to be paralyzed by her scizure. On the extreme top left of the tympanum, a woman whose body is arched in a semi-circle appears to be flung into the limbo or hell that awaits her (fig. 8). 'Ihe arched body was a hysterical posture that Charcor deemed as one of the most significant of the stage of "clownism." Another figure identified as The Martyr by Rodin may be a direct reference to Charcot's attitude passionnelle. Rodin, as in Charcot's studies, connects "hell" to the living flesh of the sufferer of hysteria.

Under the influence of evolutionary ideas there began to be some dissatisfaction among neurologists in relying solcly on localization theory to map the connections berween the brain and the body and to identify human pathologies. There was a growing interest in a stratigraphical model of functions. Brain hierarchy did not replace localization theory, but it complicated it by adding dimensions of abilities acquired through history in the evolution from primate to human. The nervous system was seen to have evolved in a kind of pyramid, with a large base in the animal world, and a certain limited number of nerves associated with refined sensibilities. ${ }^{27}$

The "animal side" of human nature was associated with the passions. Of his suffering human figures Rodin said, "Nothing is more moving than the maddened beast, perishing in lust and begging vainly for mercy from an insatiable passion." 28 Rodin called sex "our original animality." The Gates of Hell is filled with lustful figures giving in to their bodies' desires. 


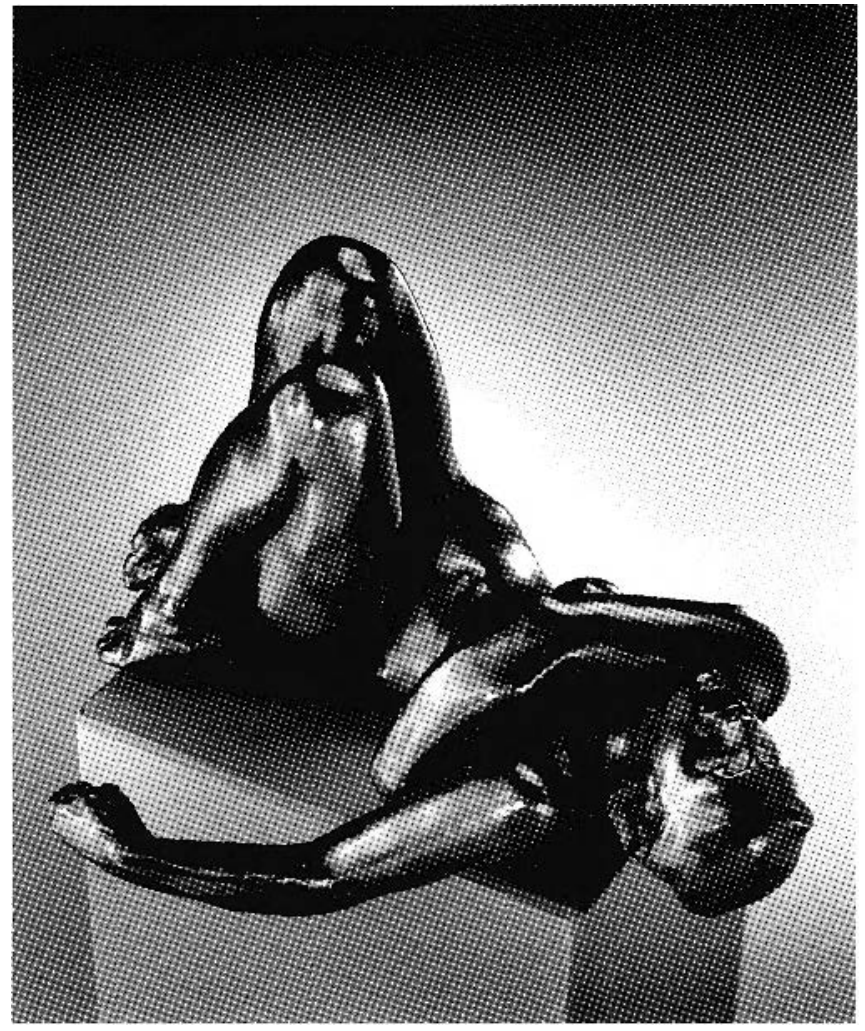

Figure II. Rodın. Damned Woman (Woman Lying on her Back), ca. 1881 Bronze. Georges Rudier I oundry, posthumous cast. 1962, $20.3 \times 39.4 \times$ $26 \mathrm{~cm}$. Stanford University Museum of Art, 1974.61. Gift of Gerald Cantor Art loundation (Photo: I rank Wing).

In an carly study, The Thinker had elongated arms and a more rounded physiquc, approximating an ape-man. ${ }^{29} \mathrm{Claude}$ Roger-Marx, early critic and friend of Rodin, identified the independent sculpture of The Ihinker as prehistoric man. In 1895 he wrote, "Rodin wished to creatc the original thinker, the thinker who enabled man to rise above the animal, the first animal inspired by the spark of divine wisdom, who struggles with convulsive pain to give birth to the first thought. It is this prehistoric man, the first, the greatest of all men, whom Rodin wished to immortalize in his statue." 30 Rodin's Thinker is posed somewhere between instinct and thought. In other works by Rodin, the "beast in humankind" is explored in a more straightforward manner. The Centauress of 1887 was at first entitled Soul and Body, and herc the human side, the torso of a woman and head, arms, and shoulders of a malc, seem to strain for release against its animal base, that of a horse. The upper body of the composite creature appears again, this time in conjunction with Large Clenched l.eft Hand (fig. 12). The

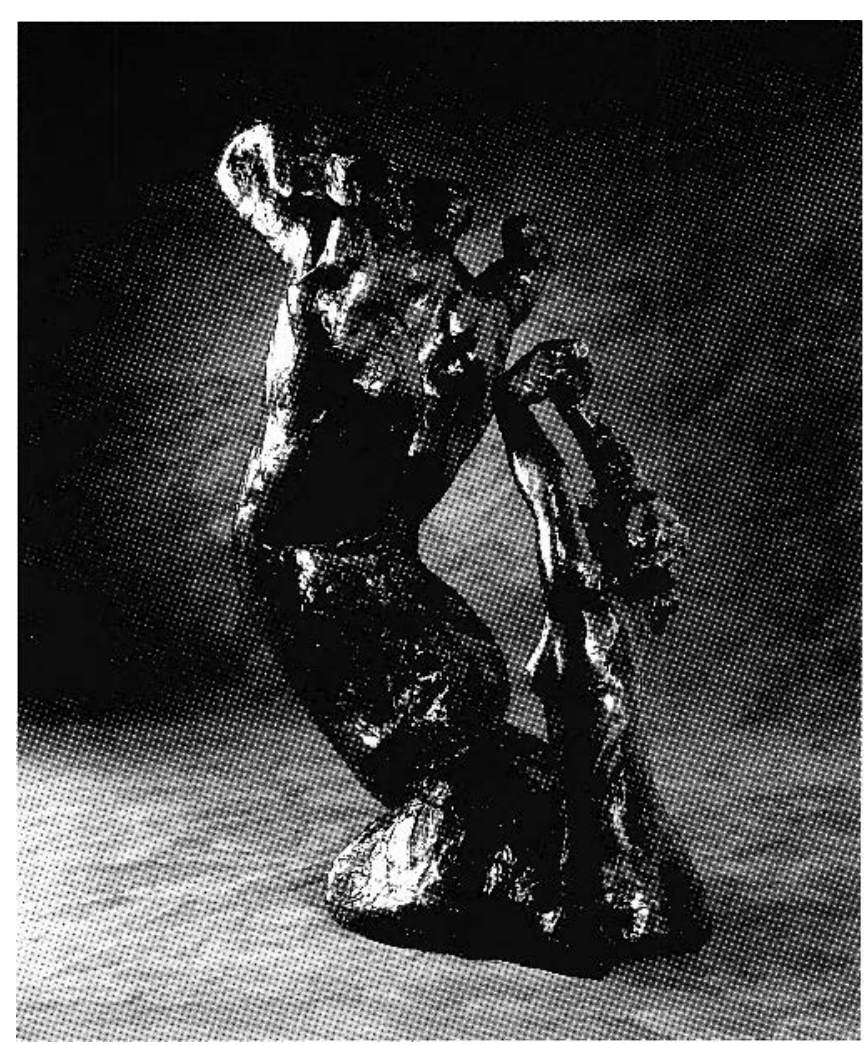

Figure 12. Rodin, Clenched Left Hand with Figurc, 1906 or 1907. Bronze, Godard Foundry. Musce Rodin cast I/12 in 1970, $44.5 \times 29.2 \times 26.4 \mathrm{~cm}$., signed and numbered A. Rodin/No 1 and inscribed Godard Fondeur Paris and (C) by Musée Rodin. Irıs and B. Gerald Cantor Collection. promised gifl to the Iris and B. Gerald Cantor Foundation (Photo: Steve Oliver).

figure seems to push toward the huge pathological hand, which is permanently contracted and incapable of crushing her. Fragments of beings, recomposed or solitary, are tied to their tragic, material histories.

Rodin, as an artist of body fragments treated as complete sculptural works, has been discussed within a rhetoric of sculptural daring and modernity. The "fragment" is conceived against the traditional representation of the whole figure or sculptural bust; but expressive individual body parts were alrcady under the scrutiny of scientists during Rodin's time as sites of ncurological communication in the context of brain localization theory. Body parts were probed with electric stimuli to tracc neurological corridors and determine pathologies. The brain itself was not only compartmentalized, but also "excavated" to determine rudimentary or more refincd sensibilities. Rodin's sculptures arc rooted in contemporary scientific experiments that mapped ncurological activity and arenas that established corresponding relationships between the body and the brain. 


\section{Acknowledgement}

The research for this article was supported by a grant from the Iris and B. Gerald Cantor Foundaton.

\section{Notes}

1 Auguste Rodin, Art: Conversations with Paul Gsell [1911], trans. Jacques de Caso and Pacricia Sanders (Berkeley, 1984), 92.

2 Judich Cladcl, Rodin: Sa vie glorieuse, et sa vie inconnue (Paris, 1936), 86

3 Cladel, Rodin, 86.

4 Christopher Goetz, Michel Bonduclle, and Toby Gelfand, Charcot: Constructing Neurology (New York, 1995), 45, 47; and Francis Schiller, Paul Broca: Founder of French Anthropology, Explorer of the Brain (1979; reprint Oxford, 1992), 273. Also see Jack Ellis, The Physician Legislators of France: Medicine and Politics in the Early Third Republic (Cambridge, 1990), 39.

5 Debora Silverman, Art Nouveau in Fin-de-Siècle France: Politics, Psychology and Style (Berkeley, 1989), 252-69; on the discussion of Rodin's hand sculptures by surgeons, sce Monique Laurent, Michel Merle, and Danièlc Gurmann, Rodin: Les Mains, les chirurgiens, exh. cat., Paris, Musée Rodin (Paris, 1983).

6 Sec Albert Elsen, Rodin's Art (New York, 2003), 587.

Rilkc, quored in Elsen, Rodin's Art, 587.

8 On the history of electricity and the nerves, see Edwin Clarke and L.S. Jacyna, Nineteenth-Century Origins of Neuroscientific Concepts (Berkeley, 1987).

9 G.-B. Duchenne de Boulogne, Mécanisme de la physionomie humaine: Analyse électro-physiologique de l'expression des passions (Paris, 1862), 5.

10 See, for examplc, Marey's "Études Graphiques sur la Nature dc la Contraction Musculairc," Journal de l'anatomie, 1 March 1866, $1-9$.

11 Elscn, Rodin's Art, 552.

12 Elsen, Rodin's Art, 555. Rodin's muscular figures relate to other experiments by Marey. Scientific research into the body's sources of energy by physiologists concerned with parhologies emphasized development of the muscle system to restorc hcalth. By $1881 \mathrm{Mar}-$ ey was running a physiological laboratory to research "muscular energy" in sports. His work was part of a broader physical culturc movement in france. The popular appeal of the amazing muscleman like the circus performer Caillou, who posed for Adam, was a result of this trend. The muscular body was the masculine ideal in late nineteenth-century France. (For additional information on the physical culturc movement and modern art, see Barbara Larson, "Curing Degeneration: Hcalth and the Neo-Classical Body in Early Twentieth-Century France," in In Sickness and in Health: Disease as Metaphor in Art and Popular Wisdom, ed. L. Dixon [Newark, 2004], 166-86). In latcr years, Rodin was close to Isadora Dun- can, whose emphasis on gymnastic training influenced Marey's colleague George Demeny, who created physical fitness programs for French children in the 1890s.

13 This discussion datcs back to Gall. Sec Anne Harrington, Medicine, Mind, and the Double Brain: A Study in Nineteenth-Century Thought (New Jersey, 1987), 9. On the relationship between probing the brain and athcism, see Jennifer Hecht, The End of the Soul: Scientific Modernity, Atheism, and Anthropology in France (New York, 2003).

14 Sce F.J. Gall and G. Spurzheim, Recherches sur le système nerveux en général et sur celui des cerveau en particulier (Paris, 1811).

15 Sćverine, "Augustc Rodin," Le Journal (Paris), 10 November 1894; cited in Frederic Grunfield, Rodin: A Biography (New York, 1987), 337.

16 For example, Paul Cisell noted that Rodin referred to his head of Falguière as "a littlc bull" and that he "often made these comparisons with the animal kingdom.... Thesc comparisons evidently facilitate the classification of physiognomies into general categories." From Rodin, Art, 65-66.

17 Anne Harrington, "A Feeling for the 'Whole': The Holistic Reaction in Neurology from the Fin de Siècle to the Interwar Years," in Mikulas Teich and Roy Porrer, eds., Fin de Siecle and Its Legacy (Cambridge, 1990), 254-78.

18 On the history of localization theory, see Robert Young, Mind, Brain and Adaptation in the Nineteenth (entury: Cerebral Localization and its Biological Context from Gall to Ferrier (Oxford, 1970); and Georges Lantéri-Laura, Evolution des Connaissances et des Doctrines sur les Localisations Cérébrales (Paris, 1977).

19 Anne Harrington, Medicine, Mind, and the Double Brain.

20 Rainer Maria Rilkc, Rodin (I.ondon, 1946), 12.

21 Quoted in Silverman, Art Nouveau in Fin-de-Siècle France, 258.

22 Quored in Albert Flsen, Rodin (New York, 1963), 53.

23 Silverman, Art Nouveau in Fin-de-Siècle France, 262-69.

24 Albert Flsen, Rodin Rediscovered, exh. cat., Washington, The Nacional Gallery (Washington, 1982), 67.

25 Goetz et al., Charcot, 207.

26 Flsen, Rodin's Art, 245.

27 On the origins of human thought and evolutionary theory in France, see Barbara Larson, The Dark Side of Nature: Science, Society and the Fantastic in the Work of Odilon Redon (University Park, PA, 2005), 49-69.

28 Quored in Albert Elsen, Rodin's Gates of Hell (Minneapolis, 1960), 69.

29 See Elsen, Rodin's Gates of Hell, plates 60, 61.

30 Quoted in Elsen, Rodin's Gates of Hell, 96. 